\title{
POLEMOLOGY AS A SUBJECT OF TEACHING IN HIGHER STUDIES
}

\author{
Milena PALCZEWSKA \\ War Studies University, Warsaw; m.palczewska@akademia.mil.pl, ORCID: 0000-0003-1601-6851
}

\begin{abstract}
Purpose: The aim of the study presented in the article is to show that polemology can be taught at higher education, in particular at Polish military academies. Due to the interdisciplinary approach to the issue of wars and armed conflicts, polemology treats the war as social phenomenon, and therefore does not focus only on military aspects.

Design/methodology/approach: The aim of the article is to determine to what extent polemology as a subject of teaching corresponds to content in education programs in military and civil studies in War Studies University. The main research problem is as follows: how students evaluate the subject content of polemology and the validity of its conduct at bachelor and master studies.

Findings: The results of empirical research also showed that polemology in its research should have a purposeful character. Such a belief leads to a dialogue in science, stimulation of creative imagination, the result of which may be: discovering original and currently important polemological problems; creating new interdisciplinary research projects; creating alternative practical solutions; setting directions of changes in science (creation of new fields and scientific disciplines).

Originality/value: The presented research shows a general approach to practicing science it should have an interdisciplinary character. There are many indications that currently practicing any scientific discipline requires companion knowledge in the field of other scientific disciplines.
\end{abstract}

Keywords: education, higher studies, polemology, war, education programs.

Category of the paper: Conceptual paper.

\section{Introduction}

The phenomena of war and peace have been the subject of interest to thinkers, philosophers, rulers of states and politicians since the dawn of time. The basis for them was research on their essence, genesis, character and meaning in the lives of individuals, societies and states. For centuries, attempts have been made to identify and understand the phenomenon of wars, while seeking means and methods that can eliminate them. Referring to historical experiences, 
it should be stated that war and armed conflicts are a social phenomenon that requires interdisciplinary, multi-aspect research.

The aim of the article is to determine to what extent polemology as a subject of teaching corresponds to content in education programs in military and civil studies in War Studies University. The main research problem is as follows: how students evaluate the subject content of polemology and the validity of its conduct at bachelor and master studies.

\section{The essence of polemology}

The word polemology is derived from the Greek word polemos, which means fighting, war. It is considered that $\mathrm{G}$. Bouthoul is its precursor. The term was meant to distinguish polemology as a field of research on war from the traditional military academies of war science. The two specialties, namely war and armed conflict, are inextricably linked with each other. There are many definitions in the literature. Referring to the words of C. Clausewitz's, a war theorist, war is nothing but an extended duel (Clausewitz, 1995, p. 3), it can be said that war in classical terms is a specific act of violence. It is based on relationships between two or more actors who deliberately choose violence in their relationships. Likewise, H. Grotius, who has formulated his definition of war, also claims that it is the state in which people are in conflict, by force (Grotius, 1957, p. 86). In this connection, the question is why violence is the main action that conflict parties take. On the one hand, a motivator is willing to change the state of things by, for example, defining a new social structure, changing areas of influence, or satisfying particular ambitions. On the other hand, all activities aim at achieving the strategic goal of victory. In a classic look, victory is nothing but the adversity of the adversary with the will that is imposed on him, as a result of the new rulers' submission (Fryc, 2009, p. 12-13).

Returning to the field of war - polemology research, it is necessary to define the subject matter of the research, the purpose and the means at its disposal. According to T. Kęson polemology is a field of science dealing with the scientific study of war. The purpose of polemology is to analyse the phenomenon of wars in a manner similar to the study of other social phenomena. It analyses their nature and the ground, location in time and space, periodicity, intensity, cause-effect relationships and typology. According to this approach, research on conflicts and wars is conducted on three levels: theoretical investigation of conflicts, discursive research into war and peace, and detailed investigation of conflict situations. On the other hand, according to E. Ponczek, polemology is a study of the war, its etiology, including reflections on undertakings concerning the possibility of eliminating military conflicts and ensuring security and the realization of peace (Ponczek, 2007, p. 7). In this context, there is an emphasis on investigating the causes of war, and on practical, 
pragmatic undertakings in the sphere of influence on consciousness, the psyche of people who might reject social aggression, and military conflict as unworthy behaviour of the individual. The definition of polemology is also found in the Lexicon of Contemporary International Political Relations. It is referred to as the area of research into wars. Deals with explaining the causes, sources, determinants of wars and armed conflicts (Mojsiewicz, 1998, p. 28).

An important aspect is that polemologists use the negative definition of peace, claiming that it is a state of no war or organized collective violence (Tuszyński, 2003, p. 7). It can be said that polemology is a variation of research into peace. However, there is a narrower approach to investigating the direct causes of war and organized violence. Less attention is devoted to political, economic and social conditions.

Polemology is based on three main pillars:

- the general sociology of war, where attention is focused on the rhythms of wariness,

- the etiology of war and virulence factors, which are designed to investigate structural, cyclical, and occasional causes of conflicts,

- $\quad$ prospection, including polemological barometers.

Polemology is considered to be a relatively young scientific specialty, but various conceptions of wars have appeared almost since the dawn of our civilization. Polemology deals with the study of armed conflicts and wars of the past, present and future. The creator of the notion of polemology, G. Bouthoul, is the author of the concept of predicting conflicts and wars. It is based on predicting the potential for a war by analysing signs and symptoms based on historical experience. Its primary research method is discursive analysis - based on the proposition - which assumes that each link in the chain of reasoning depends on the immediate precedent and affects the next one. Clarification of the sources, essence, character and effects of wars (and social conflicts) served to eliminate them and to build on this basis a lasting, universal and just peace (Rosa, Świniarski, 1995, p. 8).

The study of polemology emphasizes the need to know the war before embarking on the experience of peace. Knowing the war can create a framework for knowing peace. The basis of polemology is to observe the phenomenon of war in a similar way to the study of other social phenomena (Gałganek, 1985, p. 133).

The study of polemology assumes that the causes of wars are concentrated on three levels:

- structural causes - depending on the level of intellectual development, technological development, economic, agricultural and industrial development, demographic situation, historical and geographical conditions,

- business reasons - especially political ones - alliances, coalitions, changes and behaviour of the public under the influence of propaganda, indoctrination and ideology,

- occasional (direct) causes - unforeseen incidents, provocations, etc. 
Polemology in its research into the future development and predictions of possible wars or armed conflicts uses five polemological barometers: geographic/geopolitical factors (including geographic features, space and time), long-term factors (the theory of periodic wars), business cycles barometers of national structures (related to the state structure, development indicators, demographic indicators), short-term barometers (including the search for the causes of wars and armed conflicts in the sphere of motivation).

Polemology, whose one of the precursors is Q. Wright, also defines the cause of the war. This researcher has formulated two classifications that clarify wartime motives. The first divided into scientific, historical and practical motives - is based on the study of phenomena, properties, means and the course of wars over the history and environment that shaped the changes in war art. The second classification included technological, legal, sociological and psychological aspects (Wright, 1964). Consequently, it can be seen that war should be considered together with factors shaping the everyday lives of states and societies.

Referring to J. Bloch, war is an unavoidable phenomenon in the functioning of states and societies. History cards have shown that conflicts are almost on the agenda. Consequently, war affects all spheres of state existence. Therefore, this phenomenon should be considered politically, economically, technically and socially. Thinking about war in every country is a common concern. But this fear would increase even more if everyone realized that the economic crisis that would trigger a new war in Europe would outweigh the economic complications that accompanied the old wars, leading, perhaps, directly to the fall of today's social system (Bloch, 2005, p. 134).

Polemology assumes that war is based on the relationship between two or more actors who deliberately choose violence in mutual relations. War is by no means a human-to-human relationship, but a relationship to a state in which individuals become enemies by accident, not as people, or as citizens, but as soldiers; not as members of the motherland, but as defenders. Finally, every state can have as an enemy only other states, not people, since there can be no real relation between things of different kinds.

Polemologists claim that war proves to be a prerequisite for preserving peace and preserving security, an intermediate stage in shaping purpose-oriented, conditioned consent and harmony in every social structure. In this view, armed conflict is an integral part of building a global social order. It reflects the individual's aspirations for transformations in the economic, political, legal and ethical realm. War is therefore a dynamic factor in initiating the change of the unjust and deprecating social system. It initiates the process of constructing new political, economic, and ethical systems. It presents itself as an antithesis in the continual abrasion of opposites. War is a result of an uncontrolled increase in defensive aggression and an unrestrained desire to change status quo. The rise of this tendency to change unjust interpersonal relationships, especially at the political and economic level, will continue to be a source of social and moral conflicts and will eventually lead to the outbreak of war. 
The wars that passed and come, which are the area of study of polemology, have many common elements but also differences. Therefore, in formulating projections for future years, it is necessary to draw conclusions from the conflicts that have already occurred in human history and to take into account the trends that change the present reality. Similarly, J. Bloch, said that in fact, the war will only have one point in common with the wars of the past, namely, that its purpose will be to enslave the conqueror to fulfil the conditions dictated by the victor. In order to achieve this goal, you will have to break the opponent's strength and deprive him of the ability to continue fighting (Bloch, 1900, p. 291). Therefore, new weapons production technologies are moving towards the total destruction of the enemy using the smallest means. In addition, warfare is committed to the eradication of as many lives as possible, and the death of the civilian population is almost certainly included in the script of war.

It can be said that, in a certain way, the wars of the past have shaped societies and civilizations. From the way of life, by influencing the structure of society, to the ways and styles of government. Paradoxically, they have also influenced the strengthening of interpersonal bonds through the joint action of individuals and families against aggressors. Consequently, according to the polemological work A Study of War by Wright, it can be said that wars and armed conflicts at the turn of the century have begun to play a stronger role in society. The most negative strategy of action can be attributed to the war by implementing a population elimination function, which, with the advancement of technology, has been increasingly effective in the form of increased numbers of deaths. However, wars and armed conflicts, especially those from the beginning of civilization, have influenced the consciousness of the human population connected with the statehood and creation of the nation, the homeland. The desire to defend one's family, land, belongings, and life has increased in people's desire to fight against aggressors. There were also alliances and federations, acting in opposition to the perpetrators who laid the foundations for the present military organizations. Nevertheless, it should be borne in mind that wars and armed conflicts are governed by their separate laws, and therefore armed conflicts in which violence occurs are a specific type of political conflict. Among them we can distinguish wars as specific armed conflicts that meet three conditions:

- two or more armed parties are involved in the fighting, at least one of which is represented by regular government forces (military, paramilitary, police units),

- on both sides there must be a central organization that directs the war (even if its main aim is for defence or guerilla purposes),

- armed operations show some continuity, both sides have a planned strategy (Żukrowska, 2011, p. 50).

In today's world, wars and armed conflicts play a very different role than the acquisition of geopolitical territories. In the present situation, the possibility of deciding about peace or war in a given region will increase the status of decision-makers. The prospect of influencing public sentiment, creating fear in the population, or playing "deadly" military technology alone changes the status and role of war. Relating to history, the factors that have influenced the 
course of armed conflicts and wars were primarily the introduction of electricity, chemical weapons, aircraft and nuclear weapons. These inventions have elevated the status of more industrialized countries, as opposed to less industrial ones. In this way, there was a clear division between those states that had created the war and its actions, not just the military. In addition, the merger of the defence industry with ordinary business has intensified the role of war in society and the state.

According to Q. Wright, the phenomenon of war should be dealt with and considered from the point of view of each of the combatants. Therefore, for all those involved in the war, it is, in its simplest form, intensified by military activity, psychological tension, legal force, and social inclusion. However, this intensification cannot produce an effect until both sides of the war have comparable military strength. Referring to the point of view of the civilian population, whose state fights in war or armed conflict, this phenomenon will always be associated with increased state activity. It covers all aspects of its functioning, e.g. military, political, economic, social or cultural. Aristotle also pointed out that wars and conquests are not the purpose of the state, even though the state must be prepared for war (Aristotle, 2011, p. 185). Therefore, all technological improvements, invented and produced for the sake of wars should be regarded as good, but they are not necessarily the ultimate goal of the state, but are only the means for it.

The character and face of modern warfare have been shaped by a number of factors. Referring to Q. Wright, one of the most influential figures in the subject of war is military technology. In his book $A$ Study of War, he divided history into four periods, initiated by a particular invention that influenced the social life of the population and at the same time produced concrete military and political consequences. They are as follows: adaptation of firearms (1450-1648); professionalization of the army (1648-1789); capitalization of wars (1789-1914); totalitarianism of wars (1914-). While analysing wars and armed conflicts, these aspects should be extended to in-depth analysis of the military means available at the moment. For example, when characterising modern military technology, its advanced mechanics, increased population of the army compared to previous years, progressive militarization of society, the nationalization of national war effort, and the possibility of total war must be taken into account. In addition, Q. Wright suggests considering war together with economic, political, military and cultural changes.

The polemological approach to the cause of war represents a fundamentally interdisciplinary and historical standpoint for martial arts. It focuses on in-depth analysis of geostrategic interactions, military and political technology, political and legal factors (including national and international norms and laws), sociological and cultural factors (including religion and values), biological and political factors (including ethnic identity, age, gender), ideological factor (including concepts of peace and justice), dialogue (diplomacy, media, propaganda), the natural environment, and psychological factors that influence the causes of armed conflicts and wars. 


\section{Polemology and its development as a subject of education in the opinion of students}

In the research to this article, using the questionnaire survey, a deliberate-random selection of the sample was made. In the academic year 2017/2018 (when research was carried out), the population of students of the War Studies University in Warsaw (Poland) was about 7,000 people. The questionnaire was addressed to 210 students (which accounted for $3 \%$ of the population). Nevertheless, 17 questionnaires were not filled in the right way, which is why they were rejected and not included in the survey. This selection of the sample was mainly focused on the scope of students' knowledge related to polemology.

The research was aimed at getting acquainted with the opinions of the students of War Studies University regarding the polemological aspects functioning in the contemporary world. Finally, the survey covered 193 people, both civilian and military students.

In order to get the best out of the research results, it was assumed that the selection of respondents will be based on two target groups: civil students and officer students (soldiers). The whole group of researched persons are students of full-time and part-time studies, bachelor and master's degree at War Studies University. Such a selection of the research group was dictated by the desire to obtain information from as many respondents who have contact with polemology as possible. Due to the fact that the area of this scientific specialty is relatively little recognized outside the environment of the War Studies University, it was decided to undertake research at this University. In addition, the students who participated in the study had contact with the subject of polemology or the theoretical assumptions of polemology (depending on the degree of studies).

In the survey, using the questionnaire, the following question was asked to the students: Do you think that polemology (the area of research on wars and armed conflicts) and irenology (the area of research on peace) should be developed in the future? The question, although it seems trivial at first glance, has a justification. Establishing even obvious matters opens the way for further research steps. The accumulation of knowledge, based on research results, should be gradual.

According to the general opinion of respondents (fig. 1), as much as $83 \%$ of all surveyed students think that polemology and irenology should be areas that will be subject to continuous development in the near future. Only $6 \%$ negated this direction. It can be stated, therefore, that these scientific specialties are not sufficiently developed in the world of science. Moreover, in individual conversations of the researcher with the respondents, opinions appeared that polemology should be more widely disseminated in the academic environment. It seems reasonable to introduce subjects such as theoretical assumptions of polemology and polemology to the canon of compulsory subjects in college at military academies. Most of the respondents were also satisfied with participating in classes related to polemology. They claimed that this 
specialty gave them the opportunity to look in a completely different way on the phenomenon of wars and armed conflicts than the traditional approach identified with the art of war.

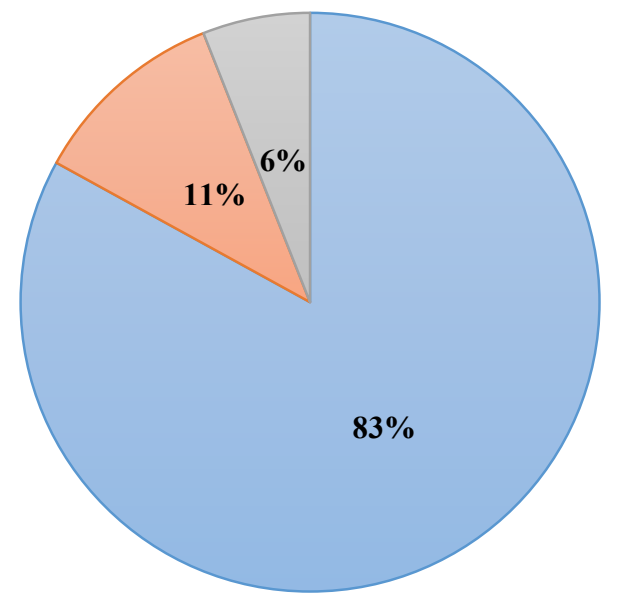

$\square$ Yes $\square$ No $\square$ I have no opinion

Figure 1. Do you think that polemology (the area of research on wars and armed conflicts) and irenology (the area of research on peace) should be developed in the future? Source: own study based on research.

Officers, unlike civilian students, refer to the phenomenon of war and armed conflicts. This is caused by their profession. Some of the military respondents were also members of the Polish Military Contingent in Afghanistan, which is why it can be concluded that their view of the war is more current than those indirectly associated with armed conflicts. The development of future of polemology may give greater research opportunities for the prospection of wars. The polemological approach in the study of armed conflicts allows the search for the causes of armed conflicts in many spheres of social life. Using the principles of prospecting allows to determine the symptoms that indicate the development of the internal or international situation in the direction of increasing the threat of the state, generated by cyclical and especially political reasons (Huzarski, 2012, p. 10).

An important issue in undertaking research efforts is to determine the perspectives for the development of polemology and irenology, as well as directions that affect the contemporary international environment. Therefore, it was decided to address the following question to the respondents: In what way, in your opinion, the changing image of societies, the mixing of races, cultures, religions, greater social mobility will affect the peace or war in the world? To the presented question, as many as $46 \%$ of respondents answered that to a large extent, while $37 \%$ chose the answer "to a medium degree", and only $13 \%$ answered that to a small extent (fig. 2). Such a range of answers indicates that the specificity of the current international situation and the social and cultural phenomena affects the subject of polemology and irenology research. In this context, it should be remembered that the basic factor of the war is hatred characteristic of the people; another - the game of probability and risk characterizing 
strategists, the next-the fact that the war grows out of some political situation and is the result of some political intention (Świeca, 1998, p. 23).

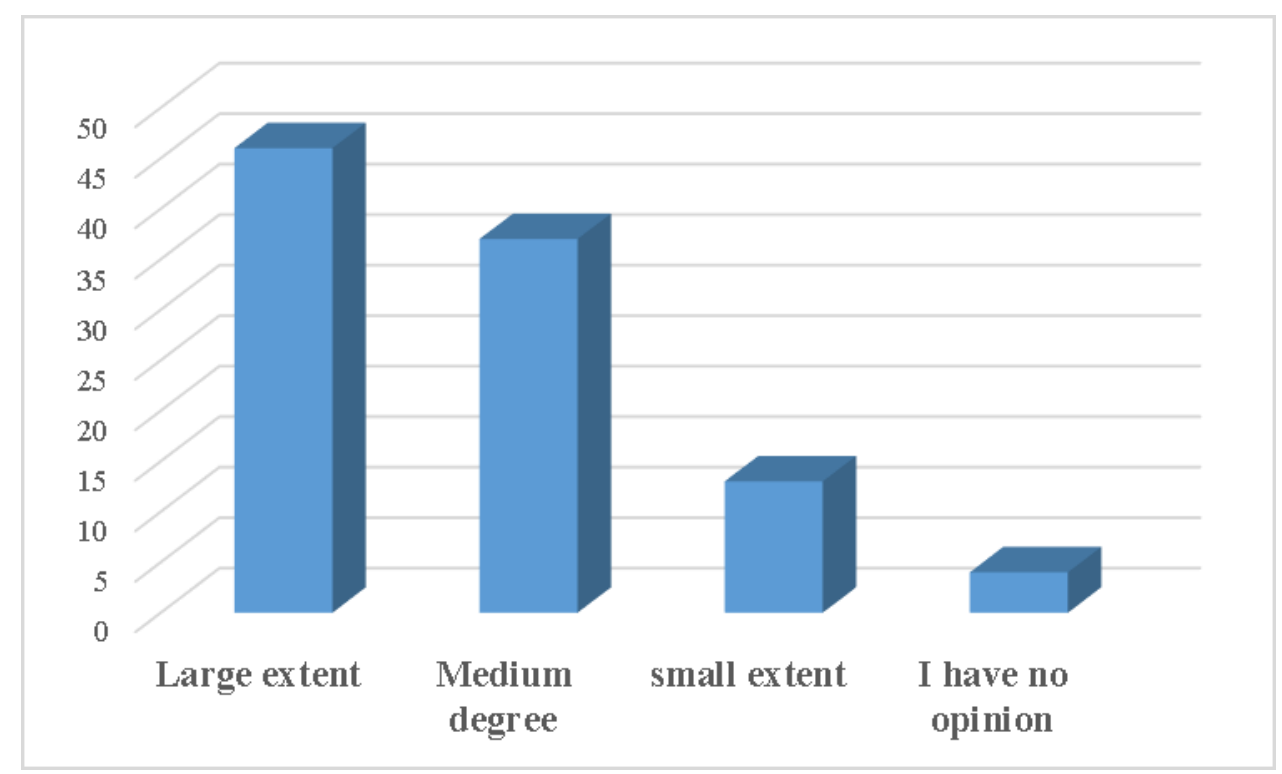

Figure 2. In what way, in your opinion, the changing image of societies, the mixing of races, cultures, religions, greater social mobility will affect the peace or war in the world? Source: own study based on research.

The factors mentioned in the question, i.e. the mixing of races, cultures, religions or greater social mobility, should be referred to the polemological theory related to the periodicity of wars. This is necessary because the periods between wars have a significant impact on society, especially in the context of demography. According to G. Bouthoul, it is essential for determining the periodicity of wars, which is connected with the end of the process of accumulation of force and the beginning of a cycle of destruction. With the end of the war, a period of relative peace begins. It is characterized by economic and demographic development until it reaches a satisfactory level. These periods follow each other, but under certain conditions cycles can be accelerated.

Referring to the results of research, the population of civilian students stated, almost in half (44\%) that the above-mentioned social phenomena to a large extent affect the image of wars and peace in the future. Such an indication confirms the belief that the young generation notices correlations of war and sociology. A sociological approach to predicting wars in the future is therefore advisable. It is societies that create nations and states that are the main actors in armed conflicts. Their transformations also affect politics, and hence geopolitics. All these factors combine in the economy, which by many experts is sometimes referred to as a factor "controlling the present world". The risk of wars is significant due to the possibility of their repetition or long duration. Eternal peace does not present economic dangers. Contrarily, it would probably facilitate the growth of the production of human labour. Eternal war would be economically deadly. War may be somewhat economically beneficial, but only in so far as people allow themselves in moderate doses. 
The peace mentioned in the question, despite the fact that it is opposed to the war, reacts in a similar way to social phenomena that sometimes shape the activities of state apparatus. Migration, economic emigration, globalization or cosmopolitanism are factors that force changes in the perception of world peace. In any situation, however, it is important not only to specify the conditions that must be met to achieve and preserve peace, but also to answer the question under what conditions a person may wish to apply such measures (Kostecki, 2012, p. 87). In this approach, peace becomes a very wide category, applicable to explaining this phenomena at all levels of the organization of social life.

The respondents were asked the question: According to your opinion, should we consider the phenomenon of war and peace along with other sciences, e.g. philosophy, history, sociology, psychology, geography? According to the data presented (fig. 3), the vast majority of respondents gave a positive answer (definitely yes and rather yes). Therefore, it should be stated that scientific disciplines such as polemology and irenology are interdisciplinary and combine with other sciences and scientific disciplines.

It can be concluded that depth and precision are the indispensable conditions for the reliability and authenticity of innovative research, including polemological research. The result of compliance with these requirements is the growing specialization of investigations conducted as part of various sciences related to particular fields. The deepening phenomenon of scientific specialization causes a natural need to include research results in a broader, interdisciplinary perspective.

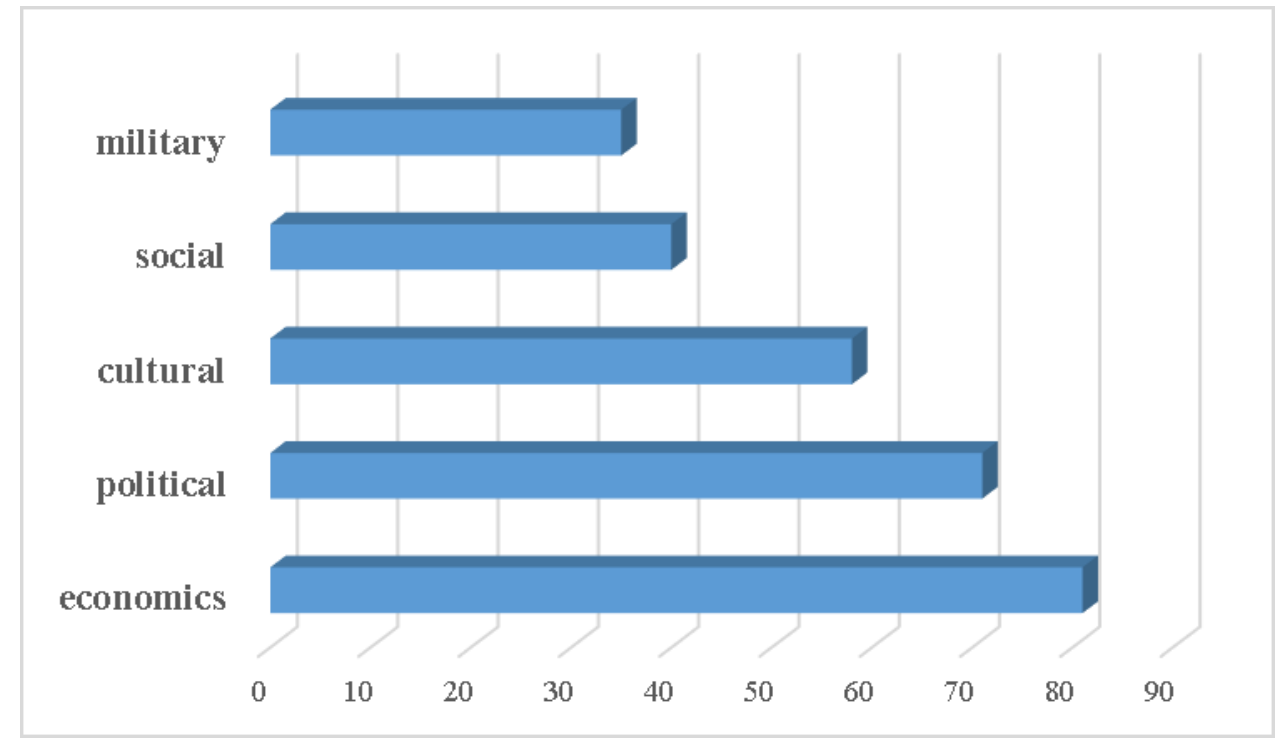

Figure 3. According to your opinion, should we consider the phenomenon of war and peace along with other sciences, e.g. philosophy, history, sociology, psychology, geography? Source: own study based on research.

As the group of students pointed out, war and peace are connected with social and humanistic sciences, such as philosophy, history, sociology, as well as with natural and technical sciences - geography or IT. Referring to the conducted research, it can be concluded that considerations going beyond institutional boundaries, usually established scientific 
disciplines, enable showing relationships between detailed results and building more comprehensive, interdisciplinary areas of knowledge. What's more, it is possible to achieve the synergy effect that comes from mutual inspiration through research that goes beyond the narrow framework of various disciplines or scientific specializations, and create conditions for authentic research innovation.

When forecasting an anticipated picture of future wars, it is first necessary to focus on possible causes of their creation. Therefore, the questionnaire included the following question: What conditions, in your opinion, will be the most common cause of future armed conflicts, wars? Respondents could indicate a maximum of three answers. Among them, economic (81\%), political (71\%) and cultural conditions (58\%) appeared most often. The distribution of all answers is presented in chart 4 . Such a proportion of responses may suggest that the students believe that in the present and future world economics and politics will play a significant role. What is more, the reduction of the role of military conditions leads towards minimizing the significance of the military power of states. Greater emphasis on the economy may cause that wars and armed conflicts in the future will be solved by other methods than it has been done so far.

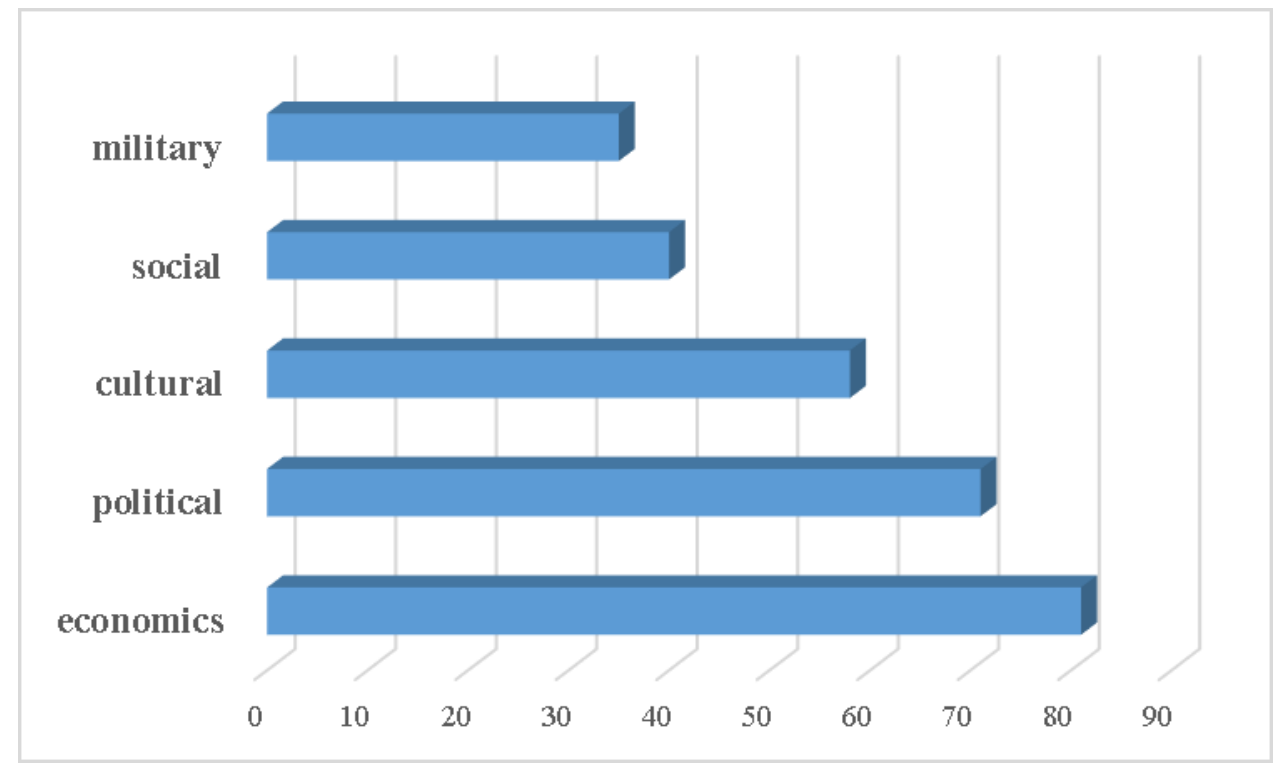

Figure 4. What conditions, in your opinion, will be the most common cause of future armed conflicts, wars? Source: own study based on research.

Referring to the results of the research, one should note the tendency that the present world is divided more than it has been seen in history so far. The first visible "dividing line" is abundance. Around 7 billion people live in the world - among them, 1/3 lives in wealth and $2 / 3$ are poor. $1 / 3$ is relatively safe (statistically, rich societies are less exposed to the phenomenon of violence), and 2/3 live in constant fear for their safety. $1 / 3$ is an information society (access to television, internet, mobile telephones, etc.), while 2/3 do not even have access to modern technologies. In this divided world, one cannot speak of the same concept of war for all the inhabitants of the globe (Prins, 2002, p. 10-11). 
While forecasting the causes of future wars and armed conflicts, the context of terrorism should also be taken into account. However, at this point it is advisable to mention the methods used by terrorists, which, read incorrectly by the special services or the armed forces of individual countries, may become a prerequisite for launching armed operations. These include: hacking attacks on servers of military organizations, automatic command systems, traffic control systems and nuclear power plants.

A trend worth mentioning is the fact that some scientists even say that in the 21 st century there is a tendency to reconstruct the classic principles of martial art by Clausewitz (Peters, 2007, p. 38-45). There are even theories related to virtual wars (electronically controlled) (Hirst, 2001, p. 92).

Military students, despite the fact that they "professionally" deal with war, did not indicate military factor as one of the most important in forecasting future wars. However, despite everything, it's worth taking a look at them. According to numerous researchers and scientists, a revolution in military matters is expected in the coming years. The first important tendency noticeable in the armed forces is the willingness to hide states own defence potential, and at the same time to acquire as much knowledge as possible related to the army of other countries. Such a situation is a consequence of the Cold War. The second issue is identified in the change in the significance of military advantage in direct combat. At present, adequate knowledge and IT systems make it possible to detain enemy troops while conducting military operations. In addition, the dependence of war on the state economy causes further barriers to the freedom to conduct armed struggle. The paradox is that forces of even much smaller numbers are now able to act in a very destructive manner towards the opposite party. The military advantage is no longer, and will not be in the future, the most important factor influencing the picture of the future wars. The third issue, maybe for some very distant, is the change of wars and armed conflicts into fully mechanized activities. Battlefields will be full of robots, and people will command them from command centres. Although this somewhat "cosmic" vision seems highly unlikely, such factors should nevertheless be taken into account, as the application of new technologies in combat may become a key factor in the explosion or, paradoxically, in the future of war and armed conflicts.

Analysing the possible shape of the future war, it is necessary to indicate the aspects that affect its transformation. Therefore, the respondents were asked the question: Which factors, in your opinion, have the greatest impact on the picture of the future war? The respondents had seven answers to choose from. The three most frequently occurring responses were (fig. 5): technology (77\%), information (73\%) and knowledge (45\%). 


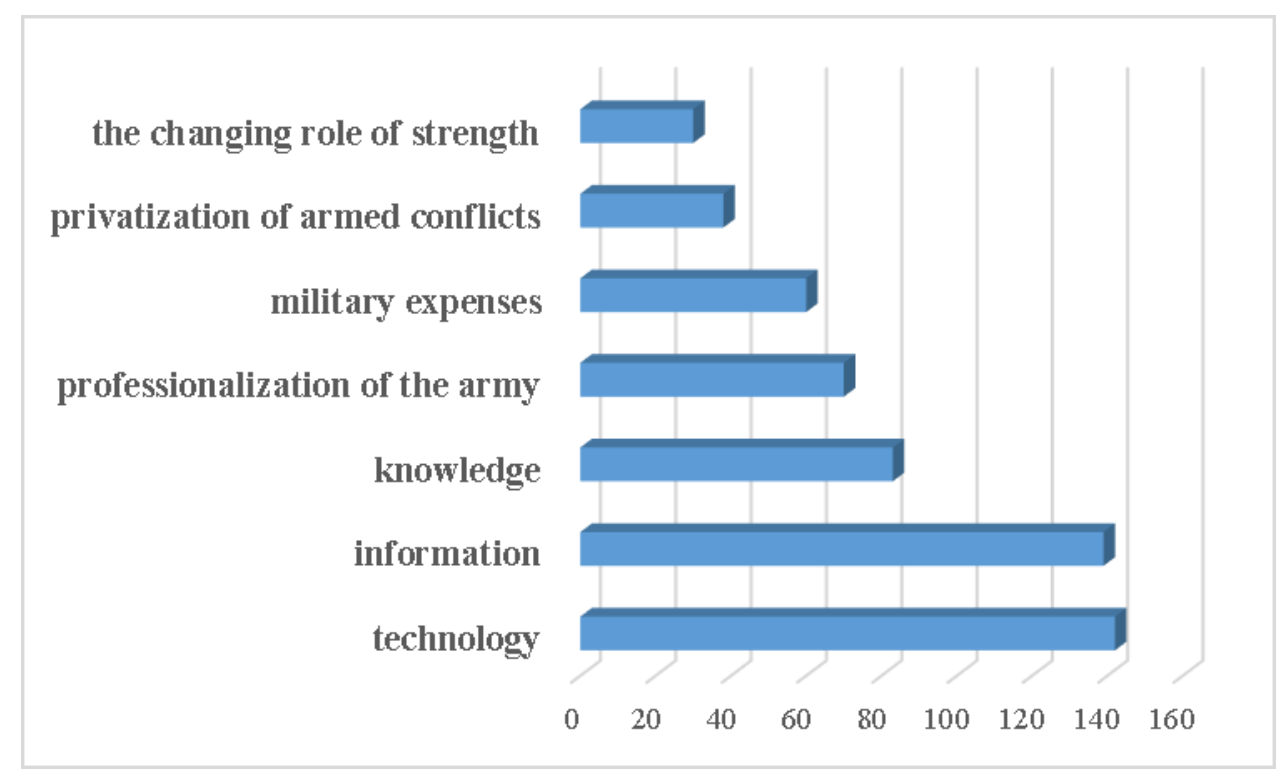

Figure 5. Which factors, in your opinion, have the greatest impact on the picture of the future war? Source: own study based on research.

Among the mentioned aspects affecting the picture of the future war, the technology and the professionalization of the army were also pointed out. It can be predicted that a lot of new equipment will be available to the soldiers. It would be a truism to say that the man is the most important. The preparation of the soldiers will therefore also cover their psyche to make them immune to anything that might harm them. Such a prepared warrior will have greater efficiency and effectiveness, which will cause that everything that will be spent on them will effect properly.

Another factor is information. In times when the information environment is based on speed, ubiquity and numerous correlations, the impact of acquiring and transmitting information is a challenge for understanding future war. However, it should be noted that the information environment carries the threat of mixing facts with fiction, truth with a lie, knowledge with assumptions. Such activities may lead to numerous conflicts in the future, although not always in a military context.

The power of information in today's and tomorrow's world, including its economic, diplomatic, technological and other forms, leads to an increase in the role of states that are in possession of the given information. This applies mainly to international leadership, in the context of the possibility of using information against other entities, and thus realizing its own strategic goals.

Knowledge is one of the most important factors indicated by the respondents, which will influence the shape of the future war. Now and in the future (also military) has the best knowledge. In addition to information that is its component, it is immaterial and impossible to evaluate directly with weapons. Knowledge, which nobody has yet had, is the most important. Many years of research by various scientists on a phenomenon that seems impossible to apply to anything comes to mind. Some scientists and researchers say that the increase in the privatization of the defence industry results from the liberalization of the market and the 
emergence of outsourcing services. In addition, as a result of the decrease in the number of professional soldiers, there is no need for as much weaponry as in the past (Mohlin, 2006, p. 154).

Armed forces have usually been the sponsor of advances in technology. We can mention here for example GPS, Internet, communication satellites or fast processors. All these innovations went into everyday use from the army. There is still a trend in which world-class scientists and engineers cooperate with representatives of arms industries and governments interested in new weapons and defence systems. It is even believed that just as the First World War has accelerated car technology, the war on terrorism will accelerate the development of automatics and robot technology. However, it should be noted that all military orders constitute a specific driver of technical and technological progress.

Wars and armed conflicts are enshrined in the coexistence of states. They are the result of the clash of various interests. Without mechanisms for the peaceful resolution of disputes and international conflicts, the world would still be ruled by force as the potential of states. The modern international order was based to a greater extent on the strength of the argument. In practice, each system is required to develop such methods and means for resolving disputes and conflicts, so that they do not pose a threat to international order and stability.

The highly complex nature of modern conflicts has caused a need for a new look and approach to ways of ensuring international peace and security, and thus a change of views on the use of military structures for this purpose. In addition, the need to quickly respond to security threats and difficulties in solving conflict situations through diplomatic and political means has made peace-keeping missions seen in the military context increasingly important.

\section{Conclusion}

Polemological knowledge about war and armed conflicts, in addition to theoretical aspect, has also an important practical side. It is associated with the belief that reality (social world) is multidimensional and its understanding should take into account the different contexts and perspectives. Therefore, the development of polemology should be based on mutual, effective cooperation of various sciences, domains and scientific disciplines (while maintaining the specificities of individual scientific disciplines).

The results of empirical research also showed that polemology in its research should have a purposeful character. Such a belief leads to a dialogue in science, stimulation of creative imagination, the result of which may be: discovering original and currently important polemological problems; creating new interdisciplinary research projects; creating alternative 
practical solutions; setting directions of changes in science (creation of new fields and scientific disciplines).

The presented research shows a general approach to practicing science - it should have an interdisciplinary character. There are many indications that currently practicing any scientific discipline requires companion knowledge in the field of other scientific disciplines. Conclusions from the conducted research can be used in the sphere of theory and practice and as tips for further research, including indicators in the formula of interdisciplinary projects.

\section{Acknowledgements}

Publication is an effect of project under the Ministry of National Defence Republic of Poland Program - Research Grant.

\section{References}

1. Aristotle (2011). Polityka. Warsaw: PWN.

2. Bloch, J. (1900). Przyszła wojna pod względem technicznym, ekonomicznym i politycznym, $V$. Kraków.

3. Bloch, J.G. (2005). Przyszła wojna pod względem technicznym, ekonomicznym i politycznym. Warsaw: PISM. CD-appendix.

4. Clausewitz, C. (1995). O wojnie. Lublin: Publisher TEST.

5. Fryc, M. (2009). Wojna. Współczesne oblicze. Toruń: MADO.

6. Gałganek, A. (1985). Polemologia jako krytyka peace research. Studies Of Political Science, 3-4, 75-76.

7. Grotius, H. (1957).O prawie wojny i pokoju. Warsaw: National Scientific Publisher.

8. Hirst, P. (2001). War and power in the 21 ${ }^{\text {st }}$ century. Padstow, Cornwall: Blackwell Publishers Inc.

9. Huzarski, M. (2012). Polemologiczne aspekty nauk o bezpieczeństwie. In: Metodologia badań bezpieczeństwa narodowego, III. Warsaw: National Defence University.

10. Kostecki, W. (2012). Bezpieczeństwo międzynarodowe wXXI wieku. Warsaw: Publisher Poltext.

11. Mohlin, M. (2006). Private military companies: a new strategic tool? In: T. Jeppson, E. Mikkola (eds.), Perspectives on the evolving nature of military power. Helsinki: Department of Strategic and Defence Studies. 
12. Mojsiewicz, Cz. (ed.) (1998). Leksykon współczesnych międzynarodowych stosunków politycznych. Wrocław: Atla 2.

13. Peters, R. (2007). Wars of blood and faith. The conflicts that will shape the twenty-first century. Mechanicsburg: StackDole Books.

14. Ponczek, E. (2006). Wojna-bezpieczeństwo-pokój w refleksji polemologicznoirenologicznej. In: G. Ciechanowski, Konflikty współczesnego świata. Toruń: Adam Marszałek.

15. Prins, G. (2002). The heart of war. On power, conflict and obligation in the twenty-first century. Padstow, Cornwall: Routledge.

16. Rosa, R., Świniarski, J. (1995). Wybrane koncepcje wojny i pokoju w dziejach myśli filozoficznej, part IV. Warsaw: National Defence University.

17. Świeca, J. (1998). Metodologiczne aspekty polemologii i peace research w XXI wieku. In: J. Świeca (ed.), Między realizmem a utopią. Katowice.

18. Tuszyński, K. (2003). Etyczne aspekty wojny i pokoju. Border security issues, 24.

19. Wright, Q. (1964). A Study of War. Abridged Edition. Chicago: University of Chicago Press.

20. Żukrowska, K. (ed.) (2011). Bezpieczeństwo międzynarodowe. Przegląd aktualnego stanu. Warsaw: Publisher IUS AT TAX. 